\title{
Opinion
}

\section{Pessimism on the Food Front}

\author{
Paul R. Ehrlich ${ }^{1, *}$ and John Harte ${ }^{2}$ \\ 1 Department of Biology, Stanford University, Stanford, CA 94305, USA \\ 2 Energy and Resources Group, University of California, Berkeley, CA 94720, USA; jharte@berkeley.edu \\ * Correspondence: pre@stanford.edu; Tel.:+1-650-723-3171
}

Received: 12 March 2018; Accepted: 5 April 2018; Published: 9 April 2018

\begin{abstract}
Virtually all trends, biophysical and socioeconomic, suggest that levels of hunger, already high, will only increase as the human population grows and its life-support systems are degraded. Steps that might ameliorate the situation are, unhappily, nowhere in sight.
\end{abstract}

Keywords: hunger; water; soil; population; climate disruption; toxins; agricultural yields

Is it likely humanity will satisfactorily feed 11 billion people around the end of this century? A quick response would be "Of course not-after 60 years of assurances that the food problem would be solved, we're not feeding 7.5 billion today". (For a pessimistic popular discussion, see http:/ / bit.ly/2BuHiLK). Indeed, the number of undernourished people in the world has been rising since 2014, reaching an estimated 815 million in 2016 [1], and several billion suffer levels of serious micronutrient malnourishment [2]. A more refined answer would consider first, the odds on there being 11 billion people in 2100 as projected by United Nations demographers, and then the biophysical and sociopolitical problems of nourishing such a mob. We will skip the question of what the future population size will be, except to note that the increasing chances of a nuclear holocaust, a deadly pandemic, and/or already plummeting human sperm counts may transform a likely lethal population explosion to a dramatic population crash.

The world's future food production faces several potentially serious biophysical constraints. One is the availability of arable land [3]. Most of the best land is already in production, and much of it is adjacent to urban centers (that is why human populations have tended to concentrate there). Furthermore, much of that land is being lost to soil erosion and degradation. The addition of more than 3 billion people to the global population seems certain to tighten this constraint. A review nearly a decade ago of the prospects for feeding "just" 9 billion people in 2050 highlighted some of the enormous hurdles the world would have to overcome in just the first half of this century [4].

A second major constraint is likely to be declining soil quantity and quality, including erosion, depletion of many nutrients not contained in fertilizer, but also degradation of soil texture, and disruption of the soil microbiome that can be critical to crop productivity [5-7]. The key nutrient phosphorus might be especially problematic, but that issue is debated [8].

Similarly, food production can also be impacted by humanity's general assault on biodiversity, especially of pollinators and the natural enemies of crop pests $[9,10]$. The deteriorating situation of pollinators has mostly focused on colony collapse disorder of honeybees, but is much broader. Populations of wild bees and other pollinating species, including butterflies and moths, birds and bats, are being pushed to extinction at startling rates.

A difficult to measure constraint is the security of the increasingly large monocultures humanity has created, the ability to control pests on them, and the toxic side effects of human control efforts. Potato agriculture and its "pesticide treadmill" presents a good example e.g., [11,12]. A related problem is the likely great increase of poisonings from microplastic/toxin interactions in marine food chains e.g., $[13,14]$. 
The most likely major biophysical constraint on future agricultural production is climate disruption, and it is already showing measurable impacts. Changing temperature and moisture regimes directly influence the ability of crops to produce. Global warming has been shown to reduce wheat production by $6 \%$ for each $1{ }^{\circ} \mathrm{C}$ increase. Higher temperatures at night can result in a substantial reduction in rice yields [15].

Climate change will very likely cause large reductions in crop yields in numerous ways. First, for all plants, including domesticated crops, there are temperature and soil moisture conditions that produce the highest yields. Not surprisingly, farmers generally know this and grow crops on their land that achieve their optimal yields under the local climate. However, as shifts in climate "push the climate envelope", yields will generally decline. Empirical studies indicate that even if we can prevent warming from exceeding $2{ }^{\circ} \mathrm{C}$, the temperature effect alone will result in at least $10 \%$ declines in yields of some important food crops [16,17]. This is optimistic, however, because water scarcity in a hotter climate will nearly certainly have even more dire impacts on agriculture. On top of that, the trajectory we are currently on will blow the planet right past the 2 degree target.

Second, roughly a third [18] of the world's crop production relies on irrigation water, much of which derives from snowmelt. The winter snowpack in mountainous regions such as the Himalayas, the Rockies, the Sierra, and the Andes is a most efficient reservoir, storing water through the cold months and releasing it gradually as snowmelt in warm months when farmers need it. Climate disruption is resulting in diminishing winter snowpacks and rapid spring runoff, thereby depriving farmers of this valuable asset, and for much of the world, there are no known substitutes. In response to severe and prolonged drought in many regions of the world, including China, India, Thailand, Italy, and California, loss of surface irrigation water has resulted in excessive pumping of groundwater, which in turn has led to land subsidence, groundwater depletion, and irreversible loss of aquifer volume [19-21].

Third, climate disruption inevitably results in catastrophic weather events that occur more frequently, are more intense, and last longer. Such extreme events include drought, superstorms such as Sandy, Harvey, and Irma, heatwaves, and vast wildfires. All of these are devastating to crop production, and the agricultural effects can linger well beyond the duration of the weather event itself. For example, extreme storms often cause extreme soil erosion, and the substitution of pumped groundwater for lost precipitation can lead to a permanent loss of arable land due to salinization of soil and land subsidence, and (as indicated above) permanent loss of aquifer storage capacity.

Fourth, food production will also likely be reduced indirectly by the impacts of climate disruption on biodiversity [22]. Warming, for example, will tend to reduce the "pest control" function of winter, converting more and more areas to "tropical" agriculture. Warming will also reduce the amount of time farmers can actually work their fields in areas where, for instance, air-conditioned tractor cabs are not available. And, sadly, adding $\mathrm{CO}_{2}$ to the atmosphere may lead to serious problems in the nutritional value of major crops [23].

Fifth, warming of the oceans may have serious impacts on fisheries productivity, and ocean acidification from the carbon dioxide humanity is pouring into the atmosphere may have even more serious consequences for the harvest from the sea e.g., [24,25]. Impacts on coral reefs are already documented and even readily visible to tourists; this is virtually certainly harming local fisheries so critical to the protein supply of many poor people [26,27].

Finally, climate disruption is already creating the dual problems of climate refugees and increasing flashpoints for conflict within and between nations. For example, drought in Syria and in the Sudan undoubtedly contributed to the eruption of conflict and displacement of people in those regions. With farmers displaced from their land, and with the disruption in food supply infrastructure that inevitably accompanies conflict, the problem of hunger is greatly exacerbated.

Even if the global climate were not disrupted, the world would likely face a severe food security crisis in the coming years. For example, we are overharvesting on both land and sea. An early signal of this is fluctuations in the prices of ocean fish, including the recent spike in the price of king salmon. 
In some regions, the cycle of fallowing and cropping, which is necessary for the sustainability of the soil, is being compromised by the necessity of feeding rapidly growing populations.

Then, of course, there are the problems of toxification and disease. While climate disruption exacerbates these problems, they also exist even under a benign climate. When we toxify our crops with hormone-mimicking pesticides, we poison ourselves [28,29]. When we pump antibiotics into our domestic animals, to a great extent, a consequence of growing animals in higher densities to increase the efficiency of high-yield husbandry, we render ourselves more vulnerable to newly evolved pathogens. A growing reliance on farmed fish and shellfish, to substitute for declining wild populations, will only increase this risk.

We suspect, however, that the greatest barrier to hope on the hunger front is sociopolitical. Above all, it arises from a combination of ignorance, politics, and the stresses on the world order from human overpopulation [30]. Although growing and gathering food is humanity's most important activity, the potential global food problem is given scant attention by either the media or in education systems. Indeed, few American college graduates know where their food comes from beyond the supermarket. Such topics as the roles of energy, trade, roads, water-handling infrastructure, and biodiversity in supplying humanity with nourishment rarely appear in classes or public discourse.

This is dramatically illustrated in the inadequate attention being paid to climate disruption. That is arguably the most serious threat to future food supplies, and yet in climate coverage more attention is paid to sea level rise, heat waves, and coastal disruption from hurricanes and superstorms. In fact, the media rarely even draw the dots connecting "weather disruption", which is given great prominence in the news, to climate disruption. It was irresponsible of the mainstream media to talk about the Texas storm, Harvey, while essentially never mentioning its connection to climate change, let alone the strong connection of population growth to both global warming and environmental disruption in general [31]. In a warming climate, higher ocean temperatures can power more intense storm events and the warmer atmosphere has the capacity to store more water, so rainstorms are more intense. Hurricane Irma, following immediately after Harvey, at least led to some discussion of connections to climate disruption (but almost none of the fossil fuel and population connections). On the negative side, both events added to an emphasis on sea-level rise among those who understand that humanity is changing the climate, to the neglect of the much more serious challenges of climate disruption to agriculture. The multiple harms that global warming is causing, especially to human access to adequate food supplies, will only increase if the science deniers continue to provide politicians with excuses to do nothing about the problem, while the media remains nearly silent.

It does not help that the most powerful nation in the world, a center of agricultural production and research, is now governed by a kakistocracy. The current Republican administration is acting contrary to the needs of society in critical areas such as agriculture, energy, environment, and water policy. Other national governments are often little better. The importance of climate disruption, biodiversity, water-handling infrastructure, the soil microbiome and so on is little appreciated by decision makers in most nations.

What would make us more optimistic that massive starvation can be avoided? First and foremost would be bringing the issues of climate change and the many dimensions of the food security situation, especially the inequity of food distribution and food wastage to the top of the policy agenda everywhere. Also important would be global efforts to redesign soil and water management practices to help agriculture to deal with climate change already entrained, steps to reduce meat consumption, public education on these, and other food-related issues, including hormone-mimicking toxins. Above all, a most hopeful sign would be more nations providing more access to modern contraception and backup abortion and truly equal rights for women. Those steps could move the world toward population reduction, the sine qua non of sustainability, and without which none of the other environmental goals are likely to be reached. 
Acknowledgments: We thank Anne Ehrlich and Mary Ellen Harte for cogent comments on the manuscript.

Author Contributions: Paul R. Ehrlich and John Harte designed the paper, gathered the information, and wrote the paper.

Conflicts of Interest: The authors declare no conflict of interest.

\section{References}

1. Food and Agriculture Organization of the United Nations (FAO). How Close Are We to \#ZeroHunger? FAO: Rome, Italy, 2017.

2. Scott, P. Global panel on agriculture and food systems for nutrition: Food systems and diets: Facing the challenges of the 21st century. Food Secur. 2017, 9, 653-654. [CrossRef]

3. Montgomery, D.R. Dirt: The Erosion of Civilizations; University of California Press: Berkeley, CA, USA, 2012.

4. Godfray, H.C.J.; Beddington, J.R.; Crute, I.R.; Haddad, L.; Lawrenc, D.; Muir, J.F.; Pretty, J.; Robinson, S.; Thomas, S.M.; Toulmin, C. Food security: The challenge of feeding 9 billion people. Science 2010, 327, 812-818. [CrossRef] [PubMed]

5. Montgomery, D.R.; Biklé, A. The Hidden Half of Nature: The Microbial Roots of Life and Health; WW Norton \& Company: New York, NY, USA, 2015.

6. Arsenault, C. Only 60 years of farming left If soil degradation continues. Sci. Am. 2014, 5, 9-11.

7. Wall, D. Soil Ecology and Ecosystem Services; Oxford University Press: Oxford, UK, 2012.

8. Cordell, D.; Drangert, J.-O.; White, S. The story of phosphorus: Global food security and food for thought. Glob. Environ. Chang. 2009, 19, 292-305. [CrossRef]

9. Ollerton, J.; Erenler, H.; Edwards, M.; Crockett, R. Extinctions of aculeate pollinators in Britain and the role of large-scale agricultural changes. Science 2014, 346, 1360-1362. [CrossRef] [PubMed]

10. Ceballos, G.; Ehrlich, A.H.; Ehrlich, P.R. The Annihilation of Nature: Human Extinction of Birds and Mammals; Johns Hopkins University Press: Baltimore, MD, USA, 2015.

11. Haverkort, A.; Boonekamp, P.; Hutten, R.; Jacobsen, E.; Lotz, L.; Kessel, G.; Visser, R.; Van der Vossen, E. Societal costs of late blight in potato and prospects of durable resistance through cisgenic modification. Potato Res. 2008, 51, 47-57. [CrossRef]

12. Mann, C.C. 1493: Uncovering the New World Columbus Created; Vintage: New York, NY, USA, 2011.

13. Mattsson, K.; Johnson, E.V.; Malmendal, A.; Linse, S.; Hansson, L.-A.; Cedervall, T. Brain damage and behavioural disorders in fish induced by plastic nanoparticles delivered through the food chain. Sci. Rep. 2017, 7, 11452. [CrossRef] [PubMed]

14. Vethaak, A.D.; Leslie, H.A. Plastic Debris Is a Human Health Issue; ACS Publications: Washington, DC, USA, 2016.

15. Watts, N.; Amann, M.; Ayeb-Karlsson, S.; Belesova, K.; Bouley, T.; Boykoff, M.; Byass, P.; Cai, W.; Campbell-Lendrum, D.; Chambers, J. The Lancet Countdown on health and climate change: From 25 years of inaction to a global transformation for public health. Lancet 2017, 391, 581-630. [CrossRef]

16. Zhao, C.; Liu, B.; Piao, S.; Wang, X.; Lobell, D.B.; Huang, Y.; Huang, M.; Yao, Y.; Bassu, S.; Ciais, P.; et al. Temperature increase reduces global yields of major crops in four independent estimates. Proc. Natl. Acad. Sci. USA 2017, 114, 9326-9331. [CrossRef] [PubMed]

17. Wheeler, T.; Von Braun, J. Climate change impacts on global food security. Science 2013, 341, 508-513. [CrossRef] [PubMed]

18. Portmann, F.T.; Siebert, S.; Döll, P. MIRCA2000-Global Monthly Irrigated and Rainfed Crop Areas around the Year 2000: A new High-Resolution Data Set for Agricultural and Hydrological Modeling. Available online: http:/ / onlinelibrary.wiley.com/doi/10.1029/2008GB003435/full (accessed on 9 April 2018).

19. Chandrakanth, M.; Romm, J. Groundwater depletion in India-Institutional management regimes. Nat. Resources J. 1990, 30, 485-501.

20. Shen, S.-L.; Xu, Y.-S. Numerical evaluation of land subsidence induced by groundwater pumping in Shanghai. Can. Geotechn. J. 2011, 48, 1378-1392. [CrossRef]

21. Galloway, D.L.; Burbey, T.J. Regional land subsidence accompanying groundwater extraction. Hydrogeol. J. 2011, 19, 1459-1486. [CrossRef]

22. Tilman, D.; Reich, P.B.; Knops, J.M.H. Biodiversity and ecosystem stability in a decadelong grassland experiment. Nature 2006, 444, 629-632. [CrossRef] [PubMed] 
23. Myers, S.S.; Zanobetti, A.; Kloog, I.; Huybers, P.; Leakey, A.D.B.; Bloom, A.J.; Carlisle, E.; Dietterich, L.H.; Fitzgerald, G.; Hasegawa, T.; et al. Increasing CO2 threatens human nutrition. Nature 2014, 510, 139-142. [CrossRef] [PubMed]

24. Ehrlich, P.R.; Harte, J. Food security requires a new revolution. Int. J. Environ. Stud. 2015, 72, 908-920. [CrossRef]

25. Vergés, A.; Steinberg, P.D.; Hay, M.E.; Poore, A.G.B.; Campbell, A.H.; Ballesteros, E.; Heck, K.L., Jr.; Booth, D.J.; Coleman, M.A.; Feary, D.A.; et al. The tropicalization of temperate marine ecosystems: Climate-mediated changes in herbivory and community phase shifts. Proc. R. Soc. B 2014, 281. [CrossRef] [PubMed]

26. Bruno, J.F.; Selig, E.R. Regional decline of coral cover in the Indo-Pacific: Timing, extent, and subregional comparisons. PLoS ONE 2007, 2, e711. [CrossRef] [PubMed]

27. Veron, J.; Hoegh-Guldberg, O.; Lenton, T.; Lough, J.; Obura, D.; Pearce-Kelly, P.; Sheppard, C.; Spalding, M.; Stafford-Smith, M.; Rogers, A. The coral reef crisis: The critical importance of $<350 \mathrm{ppm} \mathrm{CO}_{2}$. Mar. Pollut. Bull. 2009, 58, 1428-1436. [PubMed]

28. Grandjean, P.; Landrigan, P.J. Neurobehavioural effects of developmental toxicity. Lancet Neurol. 2014, 13, 330-338. [CrossRef]

29. Cribb, J. Poisoned Planet: How Constant Exposure to Man-Made Chemicals is Putting Your Life at Risk; Allen and Unwin: Crows Nest, NSW, Australia, 2014.

30. Ehrlich, P.R.; Harte, J. Opinion: To feed the world in 2050 will require a global revolution. Proc. Natl. Acad. Sci. USA 2015, 112, 14743-14744. [CrossRef] [PubMed]

31. Wynes, S.; Nicholas, K.A. The climate mitigation gap: Education and government recommendations miss the most effective individual actions. Environ. Res. Lett. 2017, 12, 091001. [CrossRef]

(C) 2018 by the authors. Licensee MDPI, Basel, Switzerland. This article is an open access article distributed under the terms and conditions of the Creative Commons Attribution (CC BY) license (http:/ / creativecommons.org/licenses/by/4.0/). 